\title{
Saberes, tempo e aprendizagem do trabalho no magistério
}

\author{
Maurice Tardif* \\ Danielle Raymond**
}

\begin{abstract}
RESUMO: Este texto trata das relações entre o tempo, o trabalho e a aprendizagem dos saberes profissionais dos professores que atuam no ensino primário e secundário, isto é, dos saberes mobilizados e empregados na prática cotidiana, saberes esses que dela se originam e que servem para dar sentido às situações de trabalho que Ihes são próprias. Este texto está dividido em três partes: inicialmente, mostraremos em que o estudo dessas relações pode ser pertinente para melhor compreender a natureza dos saberes profissionais dos professores. Em seguida, estudaremos como essas relações se expressam nos fenômenos da história da vida, da aprendizagem pré-profissional do trabalho e da carreira dos professores. Finalmente, proporemos uma reflexão e pistas teóricas sobre as diversas relações entre o tempo e os saberes profissionais.
\end{abstract}

Palavras-chave: Professores, magistério, tempo, saberes, trabalho docente À guisa de apresentação

Tal como Marx já havia enunciado, toda práxis social é, de uma certa maneira, um trabalho cujo processo de realização desencadeia uma transformação real do trabalhador. Trabalhar não é exclusivamente transformar um objeto ou situação em uma outra coisa, é também transformar a si mesmo em e pelo trabalho (Dubar 1992, 1994). Em termos sociológicos, pode-se dizer que o trabalho modifica a identidade do trabalhador,

\footnotetext{
* Professor titular da Faculdade das Ciências da Educação da Universidade de Montreal, Canadá. E-mail: maurice.tardif@videotron.ca.

** Professora da Faculdade de Educação da Universidade de Sherbrooke.
} 
pois trabalhar não é somente fazer alguma coisa, mas fazer alguma coisa de si mesmo, consigo mesmo. Como lembra Schwartz (1997, p. 7), a experiência viva do trabalho ocasiona sempre "um 'drama do uso de si mesmo', uma problemática negociação entre o uso de si por si mesmo e o uso de si pelo(s) outro(s)". Se uma pessoa ensina durante trinta anos, ela não faz simplesmente alguma coisa, ela faz também alguma coisa de si mesma: sua identidade carrega as marcas de sua própria atividade, e uma boa parte de sua existência é caracterizada por sua atuação profissional. Em suma, com o passar do tempo, ela tornou-se - aos seus próprios olhos e aos olhos dos outros - um professor, com sua cultura, seu éthos, suas idéias, suas funções, seus interesses etc.

Ora, se o trabalho modifica o trabalhador e sua identidade, modifica também, sempre com o passar do tempo, o seu "saber trabalhar". De fato, em toda ocupação, o tempo surge como um fator importante para compreender os saberes dos trabalhadores, na medida em que trabalhar remete a aprender a trabalhar, ou seja, a dominar progressivamente os saberes necessários à realização do trabalho: "a vida é breve, a arte é longa", diz o provérbio. Em certos ofícios tradicionais (por exemplo, os ofícios ligados à terra e ao mar: agricultura, salicultura, pesca etc.), o tempo de aprendizagem do trabalho confunde-se muitas vezes com o tempo da vida: o trabaIho é aprendido pela imersão no ambiente familiar e social, no contato direto e cotidiano com as tarefas dos adultos, para cuja realização as crianças e os jovens são formados pouco a pouco, muitas vezes por imitação, repetição e experiência direta do lebenwelt do labor (Jorion e Delbos 1990). Em várias outras ocupações - e é o caso do magistério -, a aprendizagem do trabalho passa por uma escolarização mais ou menos longa cuja função é fornecer aos futuros trabalhadores conhecimentos teóricos e técnicos preparatórios para o trabalho. Mas, mesmo assim, raramente acontece que essa formação teórica não tenha de ser completada com uma formação prática, isto é, com uma experiência direta do trabalho, experiência essa de duração variável e graças à qual o trabalhador se familiariza com seu ambiente e assimila progressivamente os saberes necessários à realização de suas tarefas. Em outros ofícios, a aprendizagem concreta do trabalho assume a forma de uma relação entre um aprendiz e um trabalhador experiente, como vem ocorrendo agora, cada vez mais, com a implantação dos novos dispositivos de formação para o magistério (Raymond e Lenoir 1998). Essa relação de companheirismo não se limita a uma transmissão de informações, mas desencadeia um verdadeiro processo de formação em que o aprendiz aprende, durante um período mais ou menos longo, a 
assimilar as rotinas e práticas do trabalho, ao mesmo tempo em que recebe uma formação referente às regras e valores de sua organização e ao significado que isso tem para as pessoas que praticam o mesmo ofício, por exemplo, no âmbito dos estabelecimentos escolares.

Em suma, pode-se dizer que os saberes ligados ao trabalho são temporais, pois são construídos e dominados progressivamente durante um período de aprendizagem variável, de acordo com cada ocupação. Essa dimensão temporal decorre do fato de que as situações de trabalho exigem dos trabalhadores conhecimentos, competências, aptidões e atitudes específicas que só podem ser adquiridas e dominadas em contato com essas mesmas situações (Durand 1996; Montmollin 1996; Tersac 1996). Em outras palavras, as situações de trabalho parecem irredutíveis do ponto de vista da racionalidade técnica do saber (Schön 1983), segundo a qual a prática profissional consiste numa resolução instrumental de problemas baseada na aplicação de teorias e técnicas científicas construídas em outros campos (por exemplo, através da pesquisa, em laboratórios etc.). Essas situações exigem, ao contrário, que os trabalhadores desenvolvam, progressivamente, saberes oriundos do próprio processo de trabalho e nele baseados. Ora, são exatamente esses saberes que exigem tempo, prática, experiência, hábito etc.

Interessamo-nos aqui, justamente, pelas relações entre o tempo, o trabalho e a aprendizagem dos saberes profissionais dos professores que atuam no ensino primário e secundário, isto é, dos saberes mobilizados e empregados na prática cotidiana, saberes esses que dela se originam, de uma maneira ou de outra, e que servem para resolver os problemas dos professores em exercício e para dar sentido às situações de trabalho que Ihes são próprias.

Este texto está dividido em três partes: inicialmente, diremos em que o estudo dessas relações pode ser pertinente para melhor compreender a natureza dos saberes profissionais dos professores; ao mesmo tempo, procuraremos situar-nos no campo mais amplo da literatura sobre os saberes que servem de fundamento ao ensino, precisando brevemente nossa perspectiva teórica. Em seguida, estudaremos algumas das relações entre saberes, tempo e trabalho tais como se expressam nos fenômenos da história da vida, da aprendizagem pré-profissional do trabalho e, finalmente, da carreira dos professores. Finalmente, para concluir, proporemos uma reflexão e pistas teóricas sobre as diversas relações entre o tempo e os saberes profissionais, associando isso com as questões da cognição, da identidade do trabalhador e do trabalho. ${ }^{1}$ 


\section{Por que esse interesse pelo tempo na construção dos saberes que servem de base para 0 ensino?}

Abordar a questão dos saberes dos professores do ponto de vista de sua relação com o tempo não é uma tarefa fácil em si mesma. De fato, raros são os autores que trataram diretamente dessa questão como estamos fazendo agora. Tratemos então de justificá-la e mostrar onde reside o seu interesse.

Nos últimos vinte anos, uma grande parte da literatura norte-americana sobre formação de professores e sobre formação docente tem tratado dos saberes que servem de base para o ensino, o que os pesquisadores anglo-saxões designam muitas vezes pela expressão Knowledge base. A expressão Knowledge base pode ser entendida de duas maneiras: num sentido restrito, ela designa os saberes mobilizados pelos "professores eficientes" durante a ação em sala de aula (por exemplo, nas atividades de gestão da classe e de gestão da matéria), saberes esses que foram validados pela pesquisa e que deveriam ser incorporados aos programas de formação de professores (cf. Gauthier et al. 1998); num sentido amplo, designa o conjunto dos saberes que fundamentam o ato de ensinar no ambiente escolar (Tardif e Lessard 1999). Esses saberes provêm de fontes diversas (formação inicial e contínua dos professores, currículo e socialização escolar, conhecimento das disciplinas a serem ensinadas, experiência na profissão, cultura pessoal e profissional, aprendizagem com os pares etc.). É a esse segundo significado que está ligada a nossa própria concepção.

É necessário precisar também que atribuímos à noção de "saber" um sentido amplo que engloba os conhecimentos, as competências, as habilidades (ou aptidões) e as atitudes dos docentes, ou seja, aquilo que foi muitas vezes chamado de saber, de saber-fazer e de saber-ser. Essa nossa posição não é fortuita, pois reflete o que os próprios professores dizem a respeito de seus próprios saberes. De fato, os professores que consultamos e observamos ao longo dos anos falam de vários conhecimentos, habilidades, competências, talentos, saber-fazer etc. relativos a diferentes fenômenos ligados ao seu trabalho. Eles falam, por exemplo, do conhecimento da matéria e do conhecimento relativo ao planejamento das aulas e à sua organização. Referem-se igualmente ao conhecimento dos grandes princípios educacionais e do sistema de ensino, tecendo comentários sobre os programas e livros didáticos, seu valor e sua utilidade. Salientam diversas habilidades e atitudes: gostar de trabalhar com jovens e crianças, ser capaz 
de seduzir a turma de alunos, dar provas de imaginação, partir da experiência dos alunos, ter uma personalidade atraente, desempenhar o seu papel de forma profissional sem deixar de ser autêntico, ser capaz de questionar a si mesmo. Enfim, os professores destacam bastante sua experiência na profissão como fonte primeira de sua competência, de seu "saber-ensinar".

Em resumo, como vemos, os saberes que servem de base para o ensino, tais como são vistos pelos professores, não se limitam a conteúdos bem circunscritos que dependeriam de um conhecimento especializado. Eles abrangem uma grande diversidade de objetos, de questões, de problemas que estão todos relacionados com seu trabalho. Além disso, não correspondem, ou pelo menos muito pouco, aos conhecimentos teóricos obtidos na universidade e produzidos pela pesquisa na área da Educação: para os professores de profissão, a experiência de trabalho parece ser a fonte privilegiada de seu saber-ensinar. Notemos também a importância que atribuem a fatores cognitivos: sua personalidade, talentos diversos, o entusiasmo, a vivacidade, o amor às crianças etc. Finalmente, os professores se referem também a conhecimentos sociais partilhados, conhecimentos esses que possuem em comum com os alunos enquanto membros de um mesmo mundo social, pelo menos no âmbito da sala de aula. Nesse mesmo sentido, sua integração e sua participação na vida cotidiana da escola e dos colegas de trabalho colocam igualmente em jogo conhecimentos e maneiras de ser coletivos, assim como diversos conhecimentos do trabalho partiIhados entre os pares, notadamente a respeito dos alunos e dos pais, mas também no que se refere a atividades pedagógicas, material didático, programas de ensino etc.

Os saberes profissionais dos professores parecem ser, portanto, plurais, compósitos, heterogêneos, pois trazem à tona, no próprio exercício do trabalho, conhecimentos e manifestações do saber-fazer e do saber-ser bastante diversificados, provenientes de fontes variadas, as quais podemos supor que sejam também de natureza diferente. Vários autores tentaram ordenar essa diversidade, propondo classificações ou tipologias relativas ao saber dos professores: Bourdoncle (1994), Doyle (1977), Gage (1978), Gauthier et al. (1998), Martin (1993, 1997), Mellouki e Tardif (1995), Paquay (1993), Raymond (1993), Raymond, Butt, Yamagishi (1993), Shulman (1986). Todavia, essas numerosas tipologias apresentam dois problemas maiores: por um lado, seu número e sua diversidade dão mostras do mesmo desmembramento da noção de "saber"; por outro lado, quando as comparamos, percebemos que se baseiam em elementos incomparáveis entre si. 
Por exemplo, algumas tratam de fenômenos sociais (Bourdoncle 1994), outras, de princípios epistemológicos (Shulman 1986), outras, de correntes de pesquisas (Martin 1993; Raymond 1993; Gauthier et al. 1997) ou de modelos ideais (Paquay 1993). Em suma, a proliferação dessas tipologias simplesmente desloca o problema e torna impossível uma visão mais "compreensível" dos saberes dos professores como um todo.

Há alguns anos, propusemos uma primeira tentativa de solução para essa questão do "pluralismo epistemológico" dos saberes do professor (Tardif, Lessard, Lahaye 1991) através de um modelo de análise baseado na origem social. Essa interpretação procurava associar a questão da natureza e da diversidade dos saberes do professor à de suas fontes, ou seja, de sua proveniência social. Essa abordagem nos parece válida ainda hoje. A nosso ver, ela pode mostrar-se mais útil que as diferentes tipologias propostas pelos autores precedentes para dar conta da diversidade dos saberes dos professores. Ela permite evitar a utilização de critérios epistemológicos dissonantes que reflitam os postulados teóricos dos autores, propondo, ao mesmo tempo, um modelo construído a partir de categorias relacionadas com a trajetória percorrida pelos professores ao edificarem os saberes que utilizam efetivamente em sua prática profissional cotidiana.

O quadro a seguir propõe um modelo tipológico para identificar e classificar os saberes dos professores. Ao invés de tentar propor critérios internos que permitam discriminar e compartimentar os saberes em categorias disciplinares ou cognitivas diferentes (por exemplo: conhecimentos pedagógicos e conhecimento da matéria; saberes teóricos e procedimentais etc.), ele tenta dar conta do pluralismo do saber profissional, relacionandoo com os lugares nos quais os próprios professores atuam, com as organizações que os formam e/ou nas quais eles trabalham, com seus instrumentos de trabalho e, enfim, com sua experiência no trabalho. Ele também coloca em evidência suas fontes de aquisição e seus modos de integração no trabalho docente

Esse quadro coloca em evidência vários fenômenos importantes. Em primeiro lugar, todos os saberes nele identificados são realmente usados pelos professores no contexto de sua profissão e da sala de aula. De fato, os professores utilizam constantemente seus conhecimentos pessoais e um saber-fazer personalizado, trabalham com os programas e livros didáticos, baseiam-se em saberes escolares relativos às matérias ensinadas, fiam-se em sua própria experiência e retêm certos elementos de sua formação profissional. Além disso, esse quadro registra a natureza social 
do saber profissional: pode-se constatar que os diversos saberes dos professores estão longe de serem todos produzidos diretamente por eles, que vários deles são de um certo modo "exteriores" ao ofício de ensinar, pois provêm de lugares sociais anteriores à carreira propriamente dita ou fora do trabalho cotidiano. Por exemplo, alguns provêm da família do professor, da escola que o formou e de sua cultura pessoal; outros vêm das universidades; outros são decorrentes da instituição ou do estabelecimento de ensino (programas, regras, princípios pedagógicos, objetivos, finalidades etc.); outros, ainda, provêm dos pares, dos cursos de reciclagem etc. Nesse sentido, o saber profissional está, de um certo modo, na confluência entre várias fontes de saberes provenientes da história de vida individual, da sociedade, da instituição escolar, dos outros atores educativos, dos lugares de formação etc.

\section{Quadro 1 - Os saberes dos professores}

\begin{tabular}{|c|c|c|}
\hline SABERES DOS PROFESSORES & $\begin{array}{l}\text { FONTES SOCIAIS } \\
\text { DE AQUISIÇÃO }\end{array}$ & $\begin{array}{l}\text { MODOS DE INTEGRAÇÃO } \\
\text { NO TRABALHO DOCENTE }\end{array}$ \\
\hline Saberes pessoais dos professores & $\begin{array}{l}\text { Família, ambiente de vida, a } \\
\text { educação no sentido lato etc. }\end{array}$ & $\begin{array}{c}\text { Pela história de vida e pela } \\
\text { socialização primária }\end{array}$ \\
\hline $\begin{array}{l}\text { Saberes provenientes da } \\
\text { formação escolar anterior }\end{array}$ & $\begin{array}{l}\text { A escola primária e secundária, os } \\
\text { estudos pós-secundários não } \\
\text { especializados etc. }\end{array}$ & $\begin{array}{c}\text { Pela formação e pela socialização } \\
\text { pré-profissionais }\end{array}$ \\
\hline $\begin{array}{c}\text { Saberes provenientes da } \\
\text { formação profissional para o } \\
\text { magistério }\end{array}$ & $\begin{array}{c}\text { Os estabelecimentos de formação } \\
\text { de professores, os estágios, os } \\
\text { cursos de reciclagem etc. }\end{array}$ & $\begin{array}{l}\text { Pela formação e pela socialização } \\
\text { profissionais nas instituições de } \\
\text { formação de professores }\end{array}$ \\
\hline $\begin{array}{l}\text { Saberes provenientes dos } \\
\text { programas e livros didáticos } \\
\text { usados no trabalho }\end{array}$ & $\begin{array}{l}\text { Na utilização das "ferramentas" } \\
\text { dos professores: programas, livros } \\
\text { didáticos, cadernos de exercícios, } \\
\text { fichas etc. }\end{array}$ & $\begin{array}{c}\text { Pela utilização das "ferramentas" } \\
\text { de trabalho, sua adaptação às } \\
\text { tarefas }\end{array}$ \\
\hline $\begin{array}{c}\text { Saberes provenientes de sua } \\
\text { própria experiência na profissão, } \\
\text { na sala de aula e na escola }\end{array}$ & $\begin{array}{c}\text { A prática do ofício na escola e na } \\
\text { sala de aula, a experiência dos } \\
\text { pares etc. }\end{array}$ & $\begin{array}{l}\text { Pela prática do trabalho e pela } \\
\text { socialização profissional }\end{array}$ \\
\hline
\end{tabular}

Todavia, apesar de seu interesse, uma abordagem tipológica baseada na proveniência social dos saberes parece ser relativamente simplificadora, pois dá a impressão de que todos os saberes são, de um certo modo, contemporâneos uns dos outros, imóveis e igualmente disponíveis na memória do professor, o qual buscaria nesse "reservatório de conhecimentos" aqueles que lhe são necessários no momento presente da ação. Mas as 
coisas não são tão simples assim. O que essa abordagem negligencia são as dimensões temporais do saber profissional, ou seja, sua inscrição na história de vida do professor e sua construção ao longo de uma carreira.

Essa inscrição no tempo é particularmente importante para compreender a genealogia dos saberes docentes. De fato, as experiências formadoras vividas na família e na escola ocorrem antes mesmo que a pessoa tenha desenvolvido um aparelho cognitivo aprimorado para nomear e qualificar o que ela retém dessas experiências. Além de marcadores afetivos globais conservados sob a forma de preferências ou de repulsões, a pessoa dispõe, antes de mais nada, de referenciais de tempo e de lugares para indexar e fixar essas experiências na memória. Os vestígios da socialização primária e da socialização escolar do professor ficam, portanto, fortemente marcados por referenciais de ordem temporal. Ao evocar qualidades desejáveis ou indesejáveis que quer encarnar ou evitar como professor, ele se lembrará da personalidade marcante de uma professora do quinto ano, de uma injustiça pessoal vivida na pré-escola ou das intermináveis equações impostas pelo professor de química no fim do segundo grau. A temporalidade estruturou, portanto, a memorização de experiências educativas marcantes para a construção do Eu profissional e constitui o meio privilegiado de chegar a isso. Além do mais, tal como indicam Berger e Luckman (1980), a temporalidade é uma estrutura intrínseca da consciência: ela é coercitiva. Uma seqüência de experiências de vida não pode ser invertida. Não há operação lógica que possa fazer com que se volte ao ponto de partida e com que tudo recomece. A estrutura temporal da consciência proporciona a historicidade que define a situação de uma pessoa em sua vida cotidiana como um todo e lhe permite atribuir, muitas vezes a posteriori, um significado e uma direção à sua própria trajetória de vida. $\mathrm{O}$ professor que busca definir seu estilo e negociar, em meio a solicitações múltiplas e contraditórias, formas identitárias aceitáveis para si e para os outros (Dubar 1992,1994) utilizará referenciais espaço-temporais que considera válidos para alicerçar a legitimidade das certezas experienciais que reivindica. Em relação à temática deste texto, dois fenômenos merecem uma atenção particular.

Em primeiro lugar, a trajetória pré-profissional. Como mostra uma abundante literatura (ver sínteses em Carter e Doyle 1996; Raymond 1998a e 1998b; Wideen, Mayer-Smith e Moon 1998), uma boa parte do que os professores sabem sobre o ensino, sobre os papéis do professor e sobre como ensinar provém de sua própria história de vida, principalmente de sua socialização enquanto alunos. Os professores são trabalhadores que foram 
imersos em seu lugar de trabalho durante aproximadamente 16 anos (em torno de 15.000 horas), antes mesmo de começarem a trabalhar. Essa imersão se expressa em toda uma bagagem de conhecimentos anteriores, de crenças, de representações e de certezas sobre a prática docente. Ora, o que se sabe hoje é que esse legado da socialização escolar permanece forte e estável através do tempo. Na América do Norte, percebe-se que a maioria dos dispositivos de formação inicial dos professores não consegue mudá-los nem abalá-los. Os alunos passam através da formação inicial para o magistério sem modificar substancialmente suas crenças anteriores sobre o ensino. E, tão logo começam a trabalhar como professores, sobretudo no contexto de urgência e de adaptação intensa que vivem quando começam a ensinar, são essas mesmas crenças e maneiras de fazer que reativam para solucionar seus problemas profissionais.

Em segundo lugar, a trajetória profissional. Os saberes dos professores são temporais, pois são utilizados e se desenvolvem no âmbito de uma carreira, isto é, ao longo de um processo temporal de vida profissional de longa duração no qual intervêm dimensões identitárias, dimensões de socialização profissional e também fases e mudanças. A carreira é também um processo de socialização, isto é, um processo de marcação e de incorporação dos indivíduos às práticas e rotinas institucionalizadas das equipes de trabalho. Ora, essas equipes de trabalho exigem que os indivíduos se adaptem a essas práticas e rotinas, e não o inverso. Do ponto de vista profissional e da carreira, saber como viver numa escola é tão importante quanto saber ensinar na sala de aula. Nesse sentido, a inserção numa carreira e o seu desenrolar exigem que os professores assimilem também saberes práticos específicos aos lugares de trabalho, com suas rotinas, valores, regras etc.

É portanto nesses dois fenômenos essencialmente temporais - a trajetória pré-profissional e a carreira - que desejamos nos demorar nas páginas seguintes. Começaremos pelo estudo das fontes pessoais (ou préprofissionais) do saber-ensinar; em seguida, abordaremos as relações entre os saberes e a carreira. Na conclusão, tentaremos destacar, a partir desses fenômenos, certas relações entre os saberes, o tempo e o trabalho.

\section{As fontes pré-profissionais do saber-ensinar: uma história pessoal e social}

A socialização é um processo de formação do indivíduo que se estende por toda a história de vida e comporta rupturas e continuidades. 
Nesta seção, vamos tratar da socialização pré-profissional, que compreende as experiências familiares e escolares dos professores.

Em sociologia, não existe consenso em relação à natureza dos saberes adquiridos através da socialização. Schütz (1987) fala de "tipos" cognitivos que permitem incorporar as experiências cotidianas em um reservatório (stock) das categorias cognitivas e lingüísticas. Depois de Schütz, Berger e Luckman (1980), retomados mais tarde por Dubar (1991), falaram de saberes de base pré-reflexivos e pré-dados que funcionam como evidências e como uma reserva de categorias graças às quais a criança tipifica, ordena e objetiva seu mundo. Bourdieu (1980) os associa a esquemas interiorizados (habitus) que organizam as experiências sociais e permitem gerá-las. Os etnometodologistas (Coulon 1993) os comparam a regras pré-reflexivas que estruturam as interações cotidianas. Giddens (1987) designa-os pelo termo de "competência", que estrutura a consciência prática dos atores sociais. Os cognitivistas falam dos conhecimentos anteriores estocados na memória a longo prazo em forma de figuras ou de esquemas; outros autores falam de "preconcepções", de teorias implícitas, de crenças etc. De qualquer modo, trata-se de dar conta dos desempenhos e das capacidades sociais e culturais dos indivíduos, desempenhos e capacidades que são ricos, variados e variegados, por meio de um conjunto mais restrito de saberes subjacentes que permitem compreender como esses desempenhos e capacidades são gerados. A idéia de base é que esses "saberes" (esquemas, regras, hábitos, procedimentos, tipos, categorias etc.) não são inatos, mas produzidos pela socialização, isto é, através do processo de imersão dos indivíduos nos diversos mundos socializados (famílias, grupos, amigos, escolas etc.), nos quais eles constroem, em interação com os outros, sua identidade pessoal e social.

No ensino, os trabalhos dedicados às histórias de vida de professores remontam aos anos 1980 , e os que são dedicados à socialização préprofissional datam somente de uma década. Esses trabalhos defendem a idéia de que a prática profissional dos professores põe em jogo saberes oriundos da socialização anterior à preparação profissional formal para o ensino. Eles mostram (Carter e Doyle 1996; Raymond et al. 1993; Raymond 1998a e 1998b) que há muito mais continuidade do que ruptura entre o conhecimento profissional do professor e as experiências pré-profissionais, especialmente aquelas que marcam a socialização primária (família e ambiente de vida), assim como a socialização escolar enquanto aluno.

Ao longo de sua história de vida pessoal e escolar, supõe-se que o futuro professor interioriza um certo número de conhecimentos, de compe- 
tências, de crenças, de valores etc., os quais estruturam a sua personalidade e as suas relações com os outros (especialmente com os alunos) e são reatualizados e reutilizados, de maneira não reflexiva mas com grande convicção, na prática de seu ofício. Desse ponto de vista, os saberes experienciais do professor de profissão, longe de serem baseados unicamente no trabalho em sala de aula, decorreriam, em grande parte, de preconcepções do ensino e da aprendizagem herdadas da história escolar.

Todavia, considerando que a maioria dos trabalhos empíricos dedicados a essa questão é de origem anglo-saxônica, não é certo que os seus resultados sejam diretamente aplicáveis ao grupo de professores que estudamos (professores francófonos do Quebec). As únicas pesquisas que tratam explicitamente dos professores do Quebec são aquelas realizadas por Raymond et al. (1993) ${ }^{2}$ e por Lessard e Tardif (1996). São, portanto, os resultados dessas pesquisas que vamos apresentar e discutir brevemente.

\section{A pesquisa de Raymond, Butt e Yamagishi (1993)}

Ao mesmo tempo em que propõem uma síntese teórica de outros trabalhos, esses autores apresentam assim os seus resultados:

Todas as autobiografias mencionam que experiências realizadas antes da preparação formal para o magistério levam não somente a compreender o sentido da escolha da profissão, mas influem na orientação e nas práticas pedagógicas atuais das professoras e professores. (p. 149)

Eles identificam, então, vários fenômenos que confirmam essa constatação. Por exemplo, a vida familiar e as pessoas significativas na família aparecem como fonte de influência muito importante que modela a postura da pessoa toda em relação ao ensino. As experiências escolares anteriores e as relações determinantes com professores contribuem também para modelar a identidade pessoal dos professores e seu conhecimento prático. Acrescentam-se a isso, também, experiências marcantes com outros adultos, no âmbito de atividades extra-escolares ou outras (atividades coletivas: esportes, teatro etc.). Os autores notam também, nos alunos em formação, "a persistência dos saberes sobre a adolescência expressos em termos de impressões, de percepções globais e de juízos indiferenciados, fortemente impregnados de afetos. Esses saberes comportam padrões de atribuição, 
explicações, teorias psicológicas implícitas referentes a diversas características dos adolescentes" (p. 159). Além disso, os escritos autobiográficos "fazem referência, com mais freqüência e mais explicitamente, aos amigos, a experiências vividas com grupos de pares ou às relações amorosas por eles vividas para identificar as fontes de suas representações" (pp. 160-161).

Diversos trabalhos biográficos, na maioria das vezes realizados por formadores no âmbito das disciplinas da formação inicial, permitem identificar experiências familiares, escolares ou sociais, citadas pelos alunosprofessores, como fontes de suas convicções, crenças ou representações, freqüentemente defendidas como certezas, em relação com diversos aspectos do ofício de professor: papel do professor, aprendizagem, características dos alunos, estratégias pedagógicas, gestão da classe etc. Por exemplo, Clandinin (1986, 1989) e d'Elbaz (1983) ressaltam a contribuição das variáveis pessoais na organização cotidiana da sala de aula. No que diz respeito à socialização escolar, o estudo de Holt-Reynolds (1992) sobre as concepções do ensino e da aprendizagem entre futuros professores do secundário mostra que estes aderem "espontaneamente" a uma visão tradicionalista do ensino e do aluno. Eles resistem aos esforços de um formador que argumente em favor de uma concepção ativa do estudo e da compreensão de textos, a qual, no tangente às práticas pedagógicas, supõe que os alunos sejam levados a trabalhar o mais rapidamente possível em tarefas que exijam a manipulação e o processamento de informações. Os futuros professores rejeitam a idéia de que os alunos estejam em situação de passividade quando ouvem o professor. O que conta é que o professor apresente os conhecimentos de maneira interessante para os alunos. De acordo com esses futuros professores, "a aprendizagem dos alunos depende do interesse; se um aluno não é interessado, não aprende; certas matérias devem ser ensinadas de maneira expositiva; a aula expositiva estimula o desenvolvimento do interesse pela literatura" (Raymond 1998a).

Outros pesquisadores também se interessaram por essa questão. Em sínteses de pesquisas que tratam dos conhecimentos, das crenças e das predisposições dos alunos-professores, Borko e Putnam (1996), Calderhead (1996), Carter e Anders (1996), Carter e Doyle (1995, 1996), Richardson (1996) e Wideen et al. (1998) colocam em evidência o fato de que as crenças dos professores que se encontram em formação inicial remetem a esquemas de ação e de interpretação implícitos, estáveis e resistentes através do tempo. Pode-se formular a hipótese de que são esses esquemas que, em parte, dão origem à rotinização do ensino, na medida 
em que tendem a reproduzir os comportamentos e as atitudes que constituem a essência do papel institucionalizado do professor. É particularmente o que mostra a análise das entrevistas de Holt-Reynolds (1992), ou seja, que a visão tradicionalista do ensino tem raízes na história escolar anterior desses futuros professores, os quais concebem o ensino a partir de sua própria experiência como alunos no secundário. Eles dizem ter aprendido através de aulas expositivas em que o professor apresentava a matéria de tal maneira que suscitava e mantinha o interesse dos alunos. Além disso, eles julgam, sempre a partir de suas experiências como alunos, que seus futuros alunos serão incapazes de compreender os livros didáticos ou os textos por si mesmos. Conforme Raymond et al. (1993), esses esquemas de ação e essas teorias atributivas são, em grande parte, implícitos, fortemente impregnados de afetos e percebidos pelos jovens professores como certezas profundas. Eles resistem ao exame crítico durante a formação inicial e perduram muito além dos primeiros anos de atividade docente.

\section{A pesquisa de Lessard e Tardif $(1996,1999)$}

Embora essa pesquisa não objetivasse reconstruir a história de vida dos professores a partir de uma metodologia narrativa, elementos similares à pesquisa anterior foram espontaneamente abordados pelos professores interrogados, ou postos em evidência pela análise. Vários professores falaram da origem infantil de sua paixão e de sua opção pelo ofício de professor:

"Eu era bem pequena e já sabia que ia ensinar. É um sonho que eu queria realizar a todo custo."

Ou ainda:

"Acho que era uma coisa visceral, que estava dentro de mim, e eu nunca imaginei que poderia fazer outra coisa."

Muitos professores, particularmente as mulheres, falaram da origem familiar da escolha de sua carreira, seja porque provinham de uma família de professores, seja porque essa profissão era valorizada no meio em que viviam. Encontra-se aqui a idéia de "mentalidade de serviço" peculiar a certas ocupações femininas. A esse respeito, Atkinson e Delamont (1985) apontam uma idéia interessante com relação ao "auto-recrutamento" para o magistério: 
eles notam que, se a experiência pessoal na escola é significativa na escolha do magistério, ela seria menos importante do que o fato de ter parentes próximos na área da educação, o que refletiria um recrutamento ligado à tradição oral dessa ocupação e aos efeitos da socialização por antecipação (Lortie 1975) no ofício de professor, efeitos esses induzidos pela observação, em casa, do habitus familiar e de um dos pais concentrado em tarefas ligadas ao ensino:

"Ih! Isso já está tão longe. Você está me fazendo voltar muito longe na minha história pessoal. Talvez seja porque minha mãe foi professora."

Outros professores também falaram da influência de seus antigos professores na escolha de sua carreira e em sua maneira de ensinar:

"Eu acho que são professores que encontrei e que eu achava que eram muito interessantes com os alunos. É um retorno ao passado meio difícil, porque, naquele momento, esses professores que me marcaram, é provável que alguns deles nunca tenham sabido da influência que tiveram numa decisão que estava se formando pouco a pouco."

Outros, ainda, falaram de experiências escolares importantes e positivas, como, por exemplo, o prazer que tinham em ajudar os outros alunos da sala sempre que havia oportunidade. Em certos casos, essas experiências são suficientemente importantes e gratificantes para ter determinado a escolha da carreira:

"Sim. Pra mim, foi uma coisa que veio tranqüilamente. Eu não hesitei. Eu gostava de ajudar os outros. É preciso realmente querer ajudar os outros."

Observa-se também, em muitos professores, a persistência, na profissão, de uma importante relação afetiva com as crianças. Essa relação aparece bem antes de assumirem suas funções, aliás, antes da formação inicial, e se mantém em seguida. Os professores dão também muita importância àquilo que são enquanto "pessoas", e alguns chegam até a dizer "que foram feitos para isso, para ensinar". Um tal "sentimento" tende a naturalizar o saber-ensinar e a apresentá-lo como sendo inato:

"Ensinar é uma questão de personalidade. Uma pessoa que é capaz de tomar iniciativa, de se interessar pelos alunos, de dialogar com eles, de fazer projetos, vai se dar bem no ensino." 
Nessa perspectiva, o ensino se assemelha a uma arte:

"Ensinar é uma arte. É possível tornar certas coisas científicas, mas, comunicar-se, mesmo se a gente desenvolve certas habilidades, é sempre uma coisa emocional."

Quando os professores atribuem o seu saber-ensinar à sua própria "personalidade" ou à sua "arte", parecem estar se esquecendo justamente de que essa personalidade não é forçosamente "natural" ou "inata", mas é, ao contrário, modelada ao longo do tempo por sua própria história de vida e por sua socialização. Além disso, essa naturalização e essa personalização do saber profissional são tão fortes que resultam em práticas freqüentemente reprodutoras dos papéis e das rotinas institucionalizadas da escola. Vê-se aqui uma certa lógica circular peculiar à naturalização das práticas sociais:

"Sou um bom professor porque sou feito para esse trabalho; é uma coisa inata em mim; eu domino naturalmente a arte de ensinar; mas sou justamente um bom professor porque atendo adequadamente às expectativas sociais em relação aos comportamentos e às atitudes institucionalizadas que dão origem ao meu papel."

Em última análise, o saber-ensinar tornar-se-ia a coincidência perfeita entre a personalidade do ator e o papel do agente, ambos justificando-se assim mutuamente. Em suma, o que essa lógica circular de justificação revela é a função de mediação que a história de vida exerce entre os saberes do indivíduo e os papéis e atitudes das equipes de trabalho: a "personalidade", enquanto racionalização construída a partir do sucesso como aluno e como professor, mostra como o indivíduo responde às normas institucionalizadas e como a equipe de trabalho, em troca, seleciona e valoriza essas "personalidades" que se acham em conformidade com os papéis institucionalizados.

Definitivamente, os resultados obtidos nessas duas pesquisas (Lessard e Tardif 1996, 1999; Raymond et al. 1993) sublinham a importância da história de vida dos professores, em particular a de sua socialização escolar, tanto no que diz respeito à escolha da carreira e ao estilo de ensino quanto no que se refere à relação afetiva e personalizada no trabalho. Eles mostram que o "saber-ensinar", na medida em que exige conhecimentos de vida, saberes personalizados, competências que dependem da personalidade dos atores, de seu saber-fazer pessoal, tem suas origens na história de vida familiar e escolar dos professores de profissão. Mostram também que 
a relação com a escola já se encontra firmemente estruturada no professor iniciante e que as etapas ulteriores de sua socialização profissional não se dão em um terreno neutro. Indicam, finalmente, que o tempo de aprendizagem do trabalho não se limita à duração da vida profissional, mas cobre também a existência pessoal dos professores, os quais, de um certo modo, aprenderam seu ofício antes de iniciá-lo.

Todavia, como pertencem ao tempo da vida anterior à formação profissional formal dos atores e à aprendizagem efetiva do ofício de professor, esses saberes sozinhos não podem abranger todo o saber profissional: eles tornam possível o fato de poder fazer carreira no magistério, mas não bastam para explicar em que a experiência do trabalho é também uma fonte de conhecimentos e de aprendizagem, o que nos leva agora a considerar a construção dos saberes profissionais no próprio decorrer da carreira profissional.

\section{A carreira e a edificação temporal dos saberes profissionais}

Numa perspectiva baseada na Escola de Chicago, pode-se conceber a carreira como a trajetória dos indivíduos através da realidade social e organizacional das ocupações, pouco importa seu grau de estabilidade e sua identidade. A carreira consiste em uma seqüência de fases de integração em uma ocupação e de socialização na subcultura que a caracteriza. $O$ estudo da carreira procede, assim, tanto da análise da posição ocupada pelos indivíduos em um dado momento do tempo quanto de sua trajetória ocupacional. Na medida em que procura levar em consideração as interações entre os indivíduos e as realidades sociais representadas pelas ocupações, a análise da carreira deve apoiar-se no estudo de dois tipos de fenômenos solidários: a institucionalização da carreira e sua representação subjetiva entre os atores.

A institucionalização da carreira denota o fato de que se trata de uma realidade social e coletiva, que os indivíduos que a exercem são membros de categorias coletivas de atores que os precederam e que seguiram a mesma trajetória ou uma trajetória sensivelmente idêntica. Pertencer a uma ocupação significa, portanto, para os indivíduos, que os papéis profissionais por eles desempenhados remetem a normas que eles devem adotar em relação a essa ocupação. Essas normas não se limitam a exigências formais relativas às qualificações dos membros de uma ocupação. Elas abrangem também atitudes e comportamentos estabelecidos pela tradição 
ocupacional e por sua cultura. Além disso, essas normas não são necessariamente formalizadas; muitas delas são informais e devem ser aprendidas no âmbito da socialização profissional, no contato direto com os membros que atuam na escola, e com a experiência de trabalho.

Quanto à dimensão subjetiva da carreira, ela remete ao fato de que os indivíduos dão sentido à sua vida profissional e se entregam a ela como atores cujas ações e projetos contribuem para definir e construir sua carreira. Desse ponto de vista, a modelação de uma carreira situa-se no ponto de encontro entre a ação dos indivíduos e as normas e papéis que decorrem da institucionalização das ocupações, papéis esses que devem ser "interiorizados" e dominados pelos indivíduos para que possam fazer parte dessas ocupações. Em troca, a ação dos indivíduos contribui para remodelar as normas e papéis institucionalizados, por exemplo, alterando-os para levar em conta a situação dos novos "insumos" ou das transformações das condições de trabalho. A carreira é, portanto, fruto das transações contínuas entre as interações dos indivíduos e as ocupações; essas transações são recorrentes, ou seja, elas modificam a trajetória dos indivíduos bem como as ocupações que eles assumem.

Essa maneira de abordar a carreira, situando-a na interface entre os atores e as ocupações e considerando-a, ao mesmo tempo, como um construto psicossocial modelado pela interação dos indivíduos e dos coletivos ocupacionais, permite perceber melhor o lugar que o saber profissional ocupa nas transações entre o trabalhador e seu trabalho. De fato, vista em conexão com a história de vida e a socialização (pré-profissional e profissional), a carreira revela o caráter subjetivo, experiencial e idiossincrático do saber do professor (Butt e Raymond 1987, 1989; Butt, Raymond e Yamagishi 1988; Clandinin, 1985; Connelly e Clandinin 1985). Ela permite, ao mesmo tempo, perceber melhor a dimensão historicamente construída dos saberes, do saber-fazer e do saber-ser do professor, na medida em que estes são incorporados às suas atitudes e comportamentos por intermédio de sua socialização profissional. Desse ponto de vista, ela permite fundamentar a prática do professor - o que ele é e faz - em sua história profissional.

Acreditamos que esses poucos elementos conceituais a respeito da carreira sejam suficientes para demonstrar a necessidade de estudar os saberes profissionais dos professores, situando-os em um quadro dinâmico, genético e diacrônico. A seguir, vamos tratar inicialmente da carreira dos professores regulares e permanentes, estudando, depois, o caso dos professores que vivem em situação precária, os quais representam, atual- 
mente, uma parte importante da profissão docente e que, contrariamente aos primeiros, vivem trajetórias profissionais mais complexas e "hachuradas", com repercussões na própria aprendizagem do magistério e na edificação dos saberes profissionais.

\section{As fases iniciais da carreira e a experiência de trabalho}

Uma constatação importante ressalta do nosso material e dos outros diferentes estudos: os saberes dos professores comportam uma forte dimensão temporal, remetendo aos processos através dos quais são adquiridos no âmbito de uma carreira no magistério.

Concretamente, entre os professores que entrevistamos e que possuem um emprego estável no ensino, as bases dos saberes profissionais parecem construir-se no início da carreira, entre os três e cinco primeiros anos de trabalho. Por outro lado, o início da carreira constitui também uma fase crítica em relação às experiências anteriores e aos reajustes a serem feitos em função das realidades do trabalho. Ora, esse processo está ligado também à socialização profissional do professor e ao que numerosos autores chamaram de "choque com a realidade", "choque de transição" ou ainda "choque cultural", noções que remetem ao confronto inicial com a dura e complexa realidade do exercício da profissão, à desilusão e ao desencanto dos primeiros tempos de profissão e, de maneira geral, à transição da vida de estudante para a vida mais exigente de trabalho. Porém, antes de apresentar nossos dados sobre essas questões, vejamos o que diz a literatura a esse respeito.

Eddy (1971) fez uma descrição do início da carreira que se tornou "clássica" para o ensino, distinguindo três fases ou etapas nesse processo:

a primeira fase na transição do idealismo para a realidade é marcada pela reunião formal de orientação que ocorre vários dias antes do início do ano letivo. (p. 183) (tradução livre)

Num certo sentido, trata-se de um rito de passagem da condição de estudante à de professor. Por exemplo, os novatos descobrem que, na sala dos professores, as discussões fundamentais sobre os princípios educacionais ou sobre as orientações pedagógicas não são realmente importantes. 
A preocupação maior é de mostrar aos professores que o primeiro papel deles será o de ama-seca de um grupo de alunos cativos e turbulentos. Eles são iniciados numa burocracia que tenta regular e rotinizar tanto os alunos quanto os professores, para que tudo possa funcionar sem embaraços. Os professores devem conformar-se estritamente às regras impostas pela administração, a fim de poderem ser agentes eficientes da transmissão dessas mesmas regras aos alunos. (Eddy 1971, pp. 185-186) (tradução livre)

A segunda fase corresponde à iniciação no sistema normativo informal e na hierarquia das posições ocupadas na escola.

O grupo informal inicia os novatos na cultura e no folclore da escola. Diz-se claramente aos novatos que devem interiorizar esse sistema de normas. Essas regras informais, que tratam essencialmente de assuntos não-acadêmicos, constituem um segundo choque com a realidade para os novos professores. (Eddy 1971, p. 186) (tradução livre)

Finalmente, a terceira fase está ligada à descoberta dos alunos "reais" pelos professores. Os alunos não correspondem à imagem esperada ou desejada: estudiosos, dependentes, sensíveis às recompensas e punições, desejosos de aprender (Eddy 1971, p. 186).

Outros autores (Huberman 1989; Vonk 1988; Griffin 1985; FeimanNemser e Remillard 1996) lançam a idéia de que os cinco ou sete primeiros anos da carreira representam um período crítico de aprendizagem intensa da profissão, período esse que suscita expectativas e sentimentos fortes e, às vezes, contraditórios, nos novos professores. Esses anos constituem, segundo esses autores, um período realmente importante na história profissional do professor, determinando inclusive seu futuro e sua relação com o trabalho. Nesse sentido, os autores interessados pela socialização profissional dos professores falam de um segundo fenômeno de assinalamento que marcaria a evolução da carreira docente (Lortie 1975; Gold 1996; Zeichner e Gore 1990). Haveria duas fases durante os primeiros anos de carreira:

1) Uma fase de exploração (do primeiro ao terceiro ano), na qual o professor faz uma escolha provisória de sua profissão, inicia-se através de tentativas e erros, sente a necessidade de ser aceito por seu círculo profissional (alunos, colegas, diretores de escolas, pais de alunos etc.) e experimenta diferentes papéis. Essa fase varia de acordo com os profes- 
sores, pois pode ser fácil ou difícil, entusiasmadora ou decepcionante, e é condicionada pelas limitações da instituição. Essa fase é tão crucial que leva uma porcentagem importante (Gold 1996 fala de 33\%, baseando-se em dados americanos) de iniciantes a abandonar a profissão ou simplesmente a se questionar sobre a escolha da profissão e sobre a continuidade da carreira, conforme a importância do "choque com a realidade". É o que observa Veenman (1984, p. 144) nos seguintes termos:

\begin{abstract}
Na verdade, o choque com o real se refere à assimilação de uma realidade complexa que se apresenta incessantemente diante do novo professor, todos os dias que Deus dá. Essa realidade deve ser constantemente dominada, particularmente no momento em que a pessoa está começando a assumir suas tarefas de ensino. (tradução livre)
\end{abstract}

2) A fase de estabilização e de consolidação (do terceiro ao sétimo ano), em que o professor se investe a longo prazo na sua profissão e os outros membros da organização reconhecem que ele é capaz de fazê-lo. Essa fase se caracteriza também por uma confiança maior do professor em si mesmo (e também dos outros agentes no professor), pelo domínio dos diversos aspectos do trabalho, principalmente os aspectos pedagógicos (gestão da classe, planejamento do ensino, assimilação pessoal dos programas etc.), o que se manifesta em um melhor equilíbrio profissional e, segundo Wheeler (1992), em um interesse maior pelos problemas de aprendizagem dos alunos; em outras palavras, o professor está menos centrado em si mesmo e na matéria e mais nos alunos.

Entretanto, é preciso compreender que essa estabilização e consolidação não ocorrem naturalmente, apenas em função do tempo cronológico decorrido desde o início da carreira, mas em função dos acontecimentos constitutivos que marcam a trajetória profissional, incluindo as condições de exercício da profissão. Por exemplo, a pesquisa sobre os professores suíços de Genebra e do cantão de Vaud (Huberman 1989) indica que certas condições são necessárias não só para estrear com mais facilidade na profissão, mas também para a consolidação da profissão e a estabilização na carreira, notadamente: ter turmas fáceis; um volume de trabalho que não consuma todas as energias do professor; o apoio da direção, ao invés de um controle "policial"; um compromisso definitivo por parte da instituição (conseguir um emprego regular, estável); colegas de trabalho "acessíveis", com os quais se pode contar etc. 
O que acontece quando aplicamos essas idéias ao nosso material empírico? Será que as concepções em termos de fases e etapas propostas pela literatura se aplicam a ele e permitem fazer uma associação entre "saber, tempo e carreira"? No material que recolhemos entre os professores regulares, as relações entre o desenvolvimento do saber profissional e a carreira parecem bastante claras em vários casos.

Como dizíamos, é no início da carreira que a estruturação do saber experiencial é mais forte e importante, estando ligada à experiência de trabalho. A experiência nova proporciona aos professores, progressivamente, certezas em relação ao contexto de trabalho, possibilitando assim a sua integração no ambiente profissional, que são a escola e a sala de aula. Ela vem também confirmar sua capacidade de ensinar. Esses saberes não poderiam desempenhar seu papel predominante sem o elemento integrador, o conhecimento do eu profissional nesse ofício de relações humanas, conhecimento esse que vai dar ao professor experiente uma coloração idiossincrática. Essa tomada de consciência em relação aos diferentes elementos que fundamentam a profissão e sua integração na situação de trabalho leva à construção gradual de uma identidade profissional.

O início da carreira é acompanhado também de uma fase crítica, pois é a partir das certezas e dos condicionantes da experiência prática que os professores julgam sua formação universitária anterior. Segundo eles, muita coisa da profissão se aprende com a prática, pela experiência, tateando e descobrindo; em suma, no próprio trabalho. Ao estrearem em sua profissão, muitos professores se lembram de que estavam mal preparados, principalmente para enfrentar condições de trabalho difíceis, sobretudo do ponto de vista do interesse pelas funções, da turma de alunos, da carga de trabalho etc. Foi através da prática e da experiência que eles se desenvolveram em termos profissionais. Diz um deles:

"A formação teórica não é completamente inútil, mas não pode substituir a experiência."

\section{E outro:}

"Eu tenho a impressão de que isso é um princípio, na pedagogia: você aprende quando faz." 
Finalmente, outra fonte de aprendizagem do trabalho é a experiência dos outros, dos pares, dos colegas que dão conselhos:

"Foi a cabeça que mergulhei primeiro no ensino. É uma coisa desproporcional o que se faz nos cursos universitários comparado ao que se vive na realidade. (...) É idealista demais. A gente é obrigada a abandonar muita coisa. (...) Eu não sei se tenho idéias preconcebidas. No que se refere realmente à sala de aula, os que me ensinaram as coisas foram meus colegas à minha volta. Meus melhores professores são eles."

Essa fase crítica e de distanciamento dos conhecimentos acadêmicos anteriores leva também a reajustar as expectativas e as percepções anteriores. Uma revisão da concepção anterior do "professor ideal" faz-se necessária. Com o passar dos anos, realiza-se uma aprendizagem a fim de situar melhor os alunos, suas necessidades, suas carências etc. Com efeito, o "choque com a realidade" força a questionar essa visão idealista partilhada pelos professores novatos, visão essa que, por uma questão de sobrevivência, deve-se apagar:

"A gente pensa que tem todos os poderes, quando começa a ensinar. Estamos persuadidas de que, com a gente, a criança vai aprender tudinho. E que a gente vai ser paciente, gentil... e aí não funciona. A gente fica com um pouco menos de expectativas. A gente consegue fazer coisas interessantes, mas não faz milagres..."

Também se observa uma delimitação dos territórios de competência e de atuação do professor. As mudanças não se limitam a uma questão de eficiência, "mas à maneira de viver as coisas e de compreender seu ambiente de trabalho", no momento em que o professor consegue especificar e separar seu papel e suas responsabilidades do papel e da responsabilidade dos outros, principalmente no que diz respeito ao papel dos pais. Assim, ele consegue chegar a assumir apenas aquilo que the compete enquanto professor:

"Não é tanto o que eu vivo, isso não mudou tanto assim. Eu tenho alunos, um professor e um programa. Também tem coisas imutáveis nessa história. Mas a minha maneira de viver isso mudou. Eu sei muito mais o que me compete e o que compete aos outros, e aí consigo dormir melhor."

Ele também sabe separar as coisas no que diz respeito ao seu papel na aprendizagem dos alunos: 
"Todos esses meus anos de experiência me permitiram compreender que se pode aprender tudo com o tempo e que meu papel consiste muitas vezes em colocar o aluno na pista de uma aprendizagem possível. Certas aprendizagens são longas e, em um ano, nenhum aluno e nenhum professor podem fazer milagres. Mas se um pedaço do caminho já tiver sido feito, minha missão está cumprida."

Com o passar do tempo, os professores aprendem a conhecer e a aceitar seus próprios limites. Esse conhecimento torna-os mais flexíveis. Eles se distanciam mais dos programas, das diretrizes e das rotinas, embora os respeitando em termos gerais:

"Mas, se não der certo uma vez, eu não recomeço. Não faço a mesma coisa de novo. Apresento outra coisa. Vamos fazer outra coisa hoje. E aí começo com uma nova atividade."

O domínio progressivo do trabalho leva a uma abertura em relação à construção de suas próprias aprendizagens, de suas próprias experiências, abertura essa ligada a uma maior segurança e ao sentimento de estar dominando bem suas funções. Esse domínio está relacionado, inicialmente, com a matéria ensinada, com a didática ou com a preparação da aula. Mas são sobretudo as competências ligadas à própria ação pedagógica que têm mais importância para os professores. Eles mencionam competências de liderança, de gerenciamento, de motivação.

"Não se deve estar sempre empurrando as pessoas, dizendo: 'Vamos, façam isso.' Deve-se ir na frente, puxando as pessoas e dizendo: 'Façam como eu, sigam-me.' Essa é a minha maneira de ver as coisas."

Essas competências são adquiridas com o tempo e com a experiência de trabalho:

"Recebo com freqüência estagiários na minha sala de aula e, para eles, é sempre uma descoberta quando colocam o pé na minha sala de aula. Eles fizeram muitas disciplinas, mas eles mesmos dizem: quando você coloca o pé numa sala de aula com 25 crianças, as disciplinas que você cursou estão longe demais. São as crianças de oito e meia às três horas... É a linha de tiro... Você tem que mantê-los ocupados e ocupar-se também." 
Em suma, constata-se que a evolução da carreira é acompanhada geralmente de um domínio maior do trabalho e do bem-estar pessoal no tocante aos alunos e às exigências da profissão.

Sintetizando esta seção, constata-se, tanto na literatura consultada quanto nas entrevistas que recolhemos, que a relação entre os saberes profissionais e a carreira comporta diferentes facetas e é uma relação fundamentalmente ligada ao tempo.

Entre os professores regulares, encontra-se, em primeiro lugar, a idéia de um domínio progressivo das situações de trabalho. Esse domínio abrange os aspectos didáticos e pedagógicos, o ambiente da organização escolar e as relações com os pares e com os outros atores educativos. Entre os professores contratados, encontra-se a mesma idéia, mas o domínio do trabalho demora mais a ser realizado, por causa das numerosas mudanças que eles enfrentam.

O saber profissional possui também uma dimensão identitária, pois contribui para definir, no professor regular, um compromisso durável com a profissão e a aceitação de todas as suas conseqüências, inclusive as menos fáceis (turmas difíceis, relações às vezes tensas com os pais etc.). No professor contratado, essa dimensão identitária é menos forte, pois ele é arrastado de lá para cá; seu compromisso com a profissão existe certamente, mas as condições frustradoras com as quais ele se depara continuamente colocam-no numa situação mais difícil nesse aspecto: ele também quer se comprometer, mas as condições de emprego o repelem constantemente.

Ele encerra também aspectos psicológicos e psicossociológicos, na medida em que exige um certo conhecimento de si mesmo por parte do professor (por exemplo, conhecimento de seus limites, de seus objetivos, de seus valores etc.) e um reconhecimento pelos outros, que vêem o professor tornar-se, pouco a pouco, um de seus colegas, alguém em quem podem confiar e que não precisam vigiar ou guiar. Ainda assim, esse conhecimento de si mesmo e esse reconhecimento pelos outros representam um desafio maior para os professores contratados, pois a situação deles dificulta a sua obtenção.

Tanto entre os professores regulares quanto entre os contratados, o saber profissional comporta também uma dimensão crítica que se manifesta por meio de um distanciamento em relação aos conhecimentos adquiridos anteriormente, especialmente durante a formação universitária. Outros 
distanciamentos críticos ocorrem também em relação aos instrumentos de trabalho (programas, livros didáticos, diretrizes, regras do estabelecimento etc.), que o professor adapta pouco a pouco às suas necessidades. Essa dimensão crítica parece desempenhar um papel importante na busca da autonomia profissional, pois, graças a ela, como disse um professor entrevistado, "o professor não se sente mais observado e julgado, mas torna-se aquele que observa e que julga". Para entender as transformações e os objetos dessa dimensão crítica dos saberes experienciais, devemos levar em consideração o momento da carreira no qual ela ocorre.

Entre os professores regulares, a trajetória vivida na carreira parece também levar a uma certa superposição entre os conhecimentos do professor e a cultura profissional da equipe de trabalho e do estabelecimento. O professor tende, com freqüência, a aderir aos valores do grupo; ele partilha com outros membros sua vivência profissional e troca com eles conhecimentos sobre diversos assuntos. Em suma, torna-se um membro familiarizado com a cultura de sua profissão.

Em relação a esses diferentes elementos de análise, Giddens (1987) propõe um conceito interessante, o de rotinização, que nos parece pertinente para associar saberes, tempo e trabalho entre si. Esse conceito se aplica a um número muito grande de pesquisas sobre o ensino que colocaram em evidência seu caráter rotineiro e a importância das rotinas para entender a vida na sala de aula e o trabalho do professor. A idéia geral dessas pesquisas é que as rotinas são meios de gerir a complexidade das situações de interação e diminuir o investimento cognitivo do professor no controle dos acontecimentos. À semelhança dos modelos cognitivos simplificados da realidade, as rotinas são modelos simplificados da ação: elas servem para estruturar os atos através de uma maneira de agir estável, uniforme, repetitiva. Elas dão, assim, ao professor a possibilidade de reduzir as mais diversas situações a esquemas regulares de ação, o que lhe permite, ao mesmo tempo, concentrar sua atenção em outra coisa.

Todavia, não acreditamos que a rotinização do ensino seja apenas uma maneira de controlar os acontecimentos na sala de aula. Enquanto fenômeno de base que fundamenta a vida social, a rotinização significa que os atores agem através do tempo, fazendo de suas próprias atividades recursos para reproduzir (e às vezes modificar) essas mesmas atividades. No nosso caso, ela demonstra a forte dimensão sociotemporal do ensino, na medida em que as rotinas tornam-se parte integrante da atividade profissional, constituindo, desse modo, "maneiras de ser" do professor, seu 
"estilo", sua "personalidade profissional". Porém, a menos que o ator se torne um autômato, a rotinização de uma atividade, isto é, sua estabilização e sua regulação, que possibilitam a sua divisão e sua reprodução no tempo, repousa em um controle da ação por parte do professor, controle esse baseado na aprendizagem e na aquisição temporal das competências práticas. Ora, a força e a estabilidade desse controle não podem depender de decisões voluntárias, de escolhas, de projetos, mas sim da interiorização das regras implícitas de ação adquiridas com e na experiência. É aqui, a nosso ver, que os saberes da história de vida e os saberes do trabalho construídos nos primeiros anos da prática profissional assumem todo o seu sentido, pois formam, justamente, o alicerce das rotinas de ação, porque são, ao mesmo tempo, os fundamentos da personalidade do trabalhador. A organização do tempo escolar em etapas, ciclos e anos, a da vida na sala de aula em função das estações do ano ou das festas do calendário religioso ou civil, marcam também com pontos de referência coletivos os saberes dos professores sobre sua prática, as aprendizagens que os alunos realizam na escola, as relações com os pais e a comunidade em torno da escola. $O$ estudo de tais regularidades é, portanto, fundamental para entender a natureza social e a evolução do trabalho docente, pois elas não se reduzem a formas exteriores ou a simples hábitos, mas estruturam o sentido que os atores dão às suas atividades e às relações sociais que elas desencadeiam.

\section{À guisa de conclusão}

\section{Saberes, identidade e trabalho na linha do tempo}

O objetivo deste capítulo era estudar as relações entre os saberes profissionais dos professores, o tempo e o aprendizado do trabalho. Partimos da idéia de que o tempo é um fator importante na edificação dos saberes que servem de base ao trabalho docente. Com base nos trabalhos de Raymond et al. (1993) e Lessard e Tardif (1996, 1999), afirmamos que os saberes profissionais dos professores eram plurais, mas também temporais, ou seja, adquiridos através de certos processos de aprendizagem e de socialização que atravessam tanto a história de vida quanto a carreira. Para concluir, gostaríamos de tentar identificar algumas pistas de reflexão, de análise teórica e de pesquisa para estudos posteriores sobre esse tema do tempo. Vamos nos deter, sempre no que diz respeito ao tempo, nos dois elementos centrais deste capítulo: os saberes profissionais e a identidade do professor. 


\section{Tempo e saberes profissionais}

Das análises precedentes, surge uma constatação geral: os saberes que servem de base para o ensino ou, se assim o preferem, os fundamentos do saber-ensinar não se reduzem a um "sistema cognitivo" que, como um computador, processa as informações a partir de um programa anteriormente definido e independente tanto do contexto da ação no qual ele se insere quanto da história anterior que o precede. Na realidade, os fundamentos do ensino são, a um só tempo, existenciais, sociais e pragmáticos.

São existenciais, no sentido de que um professor "não pensa somente com a cabeça", mas "com a vida", com o que foi, com o que viveu, com aquilo que acumulou em termos de experiência de vida, em termos de lastro de certezas. Em suma, ele pensa a partir de sua história de vida não somente intelectual, no sentido rigoroso do termo, mas também emocional, afetiva, pessoal e interpessoal. Desse ponto de vista, convém ultrapassar a visão epistemológica canônica do "sujeito e do objeto", se quisermos compreender os saberes do professor. O professor não é somente um "sujeito epistêmico" que se coloca diante do mundo em uma relação estrita de conhecimento, que "processa" informações extraídas do "objeto" (um contexto, uma situação, pessoas etc.) através de seu sistema cognitivo, indo buscar, por exemplo, em sua memória, esquemas, procedimentos, representações a partir dos quais organiza as novas informações. Ele é um "sujeito existencial" no sentido forte da tradição fenomenológica e hermenêutica, isto é, um "serno-mundo", um Dasein (Heidegger 1927), uma pessoa completa, com seu corpo, suas emoções, sua linguagem, seu relacionamento com os outros e consigo mesmo. Ele é uma pessoa comprometida em e por sua própria história - pessoal, familiar, escolar, social - que lhe proporciona um lastro de certezas a partir das quais ele compreende e interpreta as novas situações que o afetam e constrói, por meio de suas próprias ações, a continuação de sua história.

As pesquisas citadas anteriormente mostram exatamente como esse lastro de certezas se constrói ao longo dos múltiplos processos de socialização por que passa o professor, e como elas se sedimentam, assumindo o papel de filtros interpretativos e compreensivos graças aos quais o professor compreende e realiza seu próprio trabalho e sua própria identidade. Nessa perspectiva, a cognição do professor parece ser largamente interpretativa e lingüística, e não "computacional": ela é menos um sistema cognitivo de processamento da informação do que um processo discursivo 
e narrativo enraizado na história de vida da pessoa, história essa portadora de sentido, de linguagens, de significados oriundos de experiências formadoras. Diferentes pesquisadores (Elbaz 1993; Carter 1993) colocaram justamente em evidência o caráter narrativo do saber docente do qual fazem parte metáforas e imagens centrais que descrevem a relação com os alunos, a relação com a autoridade, o sentimento do caring (a solicitude) etc. Nas pesquisas de campo ou nas atividades de formação em parceria, quando fazemos perguntas aos professores sobre seus saberes, isso equivale, de uma certa maneira, a levá-los a contar a história de seu saber-ensinar, através das experiências pessoais e profissionais que foram significativas para eles do ponto de vista da identidade pessoal.

Os fundamentos do ensino são sociais na medida em que, como vimos, os saberes profissionais são plurais, oriundos de fontes sociais diversas (família, escola, universidade etc.) e adquiridos em tempos sociais diferentes: tempo da infância, da escola, da formação profissional, do ingresso na profissão, da carreira... São sociais também na medida em que, em certos casos, são explicitamente produzidos e legitimados por grupos sociais, como, por exemplo, os professores universitários, as autoridades curriculares etc. Nesse sentido, pode-se dizer que a relação do professor com seus próprios saberes é acompanhada de uma relação social: a consciência profissional do professor não é um reservatório de conhecimentos no qual ele se abastece conforme as circunstâncias; ela nos parece ser amplamente marcada por processos de avaliação e de crítica em relação aos saberes situados fora do processo de socialização anterior e da prática da profissão, por exemplo, os saberes das ciências da educação transmitidos durante a formação profissional, os saberes curriculares produzidos pelos funcionários do Ministério da Educação, os saberes dos outros atores escolares (pais, orientadores educacionais etc.) que, de uma maneira ou de outra, são exteriores ao trabalho docente. $O$ uso desses saberes pelo professor implica, então, uma relação social com esses mesmos saberes, bem como com os grupos, instâncias e indivíduos que os produzem. Essas diversas relações deveriam ser abordadas por pesquisas mais profundas, a fim de conhecer melhor, conforme os grupos sociais que produzem saberes sobre o ensino, os critérios de legitimação ou de invalidação utilizados pelos professores.

Finalmente, são pragmáticos, pois os saberes que servem de base ao ensino estão intimamente ligados tanto ao trabalho quanto à pessoa do trabalhador. Trata-se de saberes ligados ao labor, de saberes sobre o trabalho, ligados às funções dos professores. E é através do cumprimento dessas 
funções que eles são mobilizados, modelados, adquiridos, como tão bem o demonstram as rotinas, em especial, e a importância que os professores dão à experiência. Trata-se, portanto, de saberes práticos ou operativos e normativos, o que significa dizer que a sua utilização depende de sua adequação às funções, aos problemas e às situações do trabalho, assim como aos objetivos educacionais que possuem um valor social. A cognição do professor é condicionada, portanto, por sua atividade; "ela está a serviço da ação" (Durand 1996). Esses saberes também são interativos, mobilizados e modelados no âmbito de interações entre o professor e os outros atores educacionais. Eles possuem, portanto, as marcas dessas interações tais como elas se estruturam nas relações de trabalho: estão, por exemplo, impregnados de normatividade e de afetividade e fazem uso de procedimentos de interpretação de situações rápidas, instáveis, complexas etc.

Ora, de modo essencial, essa tripla caracterização - existenciais, sociais e pragmáticos - demonstra a dimensão temporal dos saberes do professor, saberes esses que não somente parecem ser adquiridos no e com o tempo, mas são eles mesmos temporais, pois são abertos, porosos, permeáveis, e incorporam, ao longo do processo de socialização e da carreira, experiências novas, conhecimentos adquiridos em pleno processo, um saber-fazer remodelado em função das mudanças de prática, de situações de trabalho. Compreender os saberes dos professores é compreender, portanto, sua evolução e suas transformações e sedimentações sucessivas ao longo da história de vida e de uma carreira; história e carreira que remetem a várias camadas de socialização e de recomeços.

\section{Tempo e identidade profissional}

Ensinar é, poder-se-ia dizer, de maneira banal, fazer carreira no magistério, ou seja, entrar para uma equipe de trabalho, nela assumir um papel e desempenhar uma função, e procurar atingir objetivos particulares definidos por essa equipe. O ensino é, portanto uma questão de estatuto. Como explica Coster (1998, p. 23),

a noção de estatuto não deve ser confundida com o regime jurídico ou contratual que define legalmente a situação do trabalhador. Embora susceptível de ser visto como um conjunto de direitos e de obrigações socialmente determinados, o estatuto representa, no fundo, o aspecto normativo do papel ou o processo de institucionalização que modela esse aspecto. 
Em outros termos, o estatuto remete à questão da identidade do trabalhador tanto na organização do trabalho quanto na organização social, na medida em que estas funcionam de acordo com uma imposição das normas e regras que definem os papéis e posições dos atores. Ora, essa identidade não é simplesmente um "dado", mas também um "construto" que remete "aos atos" de agentes ativos capazes de justificar suas práticas e de dar coerência às suas escolhas (Dubar 1991, p. 14). Segundo esse autor, uma visão sociológica da identidade deve articular dois processos heterogêneos:

aquele pelo qual os indivíduos antecipam seu futuro a partir de seu passado, e aquele pelo qual eles entram em interação com os atores significativos de uma área específica. (1991, p. 14)

Aqui, nós nos interessamos muito mais pelo primeiro processo em relação com a carreira e a socialização profissional. De acordo com nossas análises, é impossível compreender a questão da identidade dos professores sem inseri-la imediatamente na história dos próprios atores, de suas ações, projetos e desenvolvimento profissional. Nossas análises indicam que a socialização e a carreira dos professores não são somente o desenrolar de uma série de acontecimentos objetivos. Ao contrário, sua trajetória social e profissional ocasiona para eles custos existenciais (formação profissional, inserção na profissão, choque com a realidade, aprendizagem na prática, descoberta de seus limites, negociação com os outros etc.) e é graças aos seus recursos pessoais que eles podem encarar esses custos e suportá-los. Ora, é claro que esse processo modela a sua identidade pessoal e profissional, e é vivendo-o por dentro, por assim dizer, que eles podem tornar-se professores e considerar-se como tais aos seus próprios olhos.

Essa historicidade se expressa e se imprime nos saberes profissionais dos professores e, mais especificamente, nos saberes experienciais adquiridos no início da carreira, que são, parcialmente, uma reativação, mas também uma transformação dos saberes adquiridos nos processos anteriores de socialização (familiar, escolar e universitária). Como vimos anteriormente, a dimensão temporal do trabalho, isto é, a experiência da prática da profissão em uma carreira, é crucial na aquisição do sentimento de competência e na implantação das rotinas do trabalho, em outras palavras, na estruturação da prática. Ainda hoje, a maioria dos professores diz que aprendem a trabalhar trabalhando. Esse aprendizado, muitas vezes difícil e ligado à fase de sobrevivência profissional, na qual o professor deve 
mostrar do que é capaz, leva à construção dos saberes experienciais que se transformam muito cedo em certezas profissionais, em truques do ofício, em rotinas, em modelos de gestão da classe e de transmissão da matéria. Esses repertórios de competências constituem o alicerce sobre o qual vão ser edificados os saberes profissionais durante o resto da carreira. Todavia, tais saberes não se limitam de modo algum a um domínio cognitivo e instrumental do trabalho docente. Eles abrangem igualmente aspectos como o bem-estar pessoal em trabalhar nessa profissão, a segurança emocional adquirida em relação aos alunos, o sentimento de estar no seu lugar, a confiança nas suas capacidades de enfrentar problemas e de poder resolvêlos (alunos difíceis, conflitos etc.), o estabelecimento de relações positivas com os colegas e com a direção etc. Em outras palavras, se é verdade que a experiência do trabalho docente exige um domínio cognitivo e instrumental da função, ela também exige uma socialização na profissão e em uma vivência profissional através das quais se constrói e se experimenta pouco a pouco uma identidade profissional, onde entram em jogo elementos emocionais, relacionais e simbólicos que permitem que um indivíduo se considere e viva como um professor e assuma, assim, subjetivamente e objetivamente, o fato de fazer carreira no magistério.

O tempo não é, definitivamente, somente um meio - no sentido de um "meio marinho" ou "aéreo" - no qual estão imersos o trabalho, o trabalhador e seus saberes; também não é unicamente um dado objetivo caracterizado, por exemplo, pela duração administrativa das horas ou dos anos de trabalho. É também um dado subjetivo, no sentido de que contribui poderosamente para modelar a identidade do trabalhador. É apenas ao cabo de um certo tempo - tempo da vida profissional, tempo da carreira - que o eu pessoal, em contato com o universo do trabalho, vai pouco a pouco se transformando e torna-se um eu profissional. A própria noção de experiência, que está no cerne do eu profissional dos professores e de sua representação do saber ensinar, remete ao tempo, concebido como um processo de aquisição de um certo domínio do trabalho e de um certo conhecimento de si mesmo.

\section{Notas}

1. No que se refere aos aspectos empírico e metodológico, este texto se apóia nas pesquisas de Lessard e Tardif (1996, 1999), baseadas em entrevistas com 150 professoras e professores de profissão, bem como em observações feitas em sala de aula e nos estabelecimentos de ensino; também foram utilizados os dados coligidos por Raymond, Butt e Yamagishi (1993). Consulte esses trabalhos para obter maiores esclarecimentos com relação 
aos procedimentos metodológicos e ao quadro teórico. Salvo indicação contrária, os trechos do discurso dos professores citados neste texto são provenientes dessas pesquisas.

2. Os autores estudaram 80 documentos autobiográficos de futuros professores e 10 histórias de vida de professores experientes. No caso dos professores experientes, foi dada uma atenção particular às experiências anteriores à preparação formal para o magistério citadas espontaneamente pelos professores.

Recebido para publicação em Julho de 2000.

\section{Wisdom, time and learning of their work by teachers}

ABSTRACT: This article presents an analysis of the relations between time, work and learning in the professional knowledge of elementaryand secondary-school teachers. This knowledge is defined as that which that is generated by practice and deployed and used in daily practice, and that gives meaning to work situations faced by teachers. The article consists of three parts; the first establishes the importance of these relations for better understanding the nature of teachers professional knowledge, or wisdom; the second examines the expression of these relations in teachers' careers, life histories and professional training. Finally, the third part discusses and presents theoretical possibilities regarding the various relationships between the concept of time and professional wisdom.

Key words: Teachers, teachers' work, time, knowledge

\section{Bibliografia}

BERGER, P.L. e LUCKMANN, T. The social construction of reality: a treatise in the sociology of knowledge. Nova lorque: Irvington Publishers, 1980.

BORKO, H. e PUTNAM. R.T. "Learning to teach". In: BERLINER, D. e CALFEE, R. (eds.), Handbook of educational psychology. Nova lorque: MacMillan, 1996, pp. 673-708.

BUTT, R.L. e RAYMOND, D. "Studying the nature and development of teachers' knowledge using collaborative autobiography". International Journal of Educational Research, 13 (4), 403-419, 1989.

. "Arguments for using qualitative approches in understanding teacher thinking: the case for biography". Journal of Curriculum Theorizing, 7, 62-93, 1987. 
BUTT, R.L.; RAYMOND, D. e YAMAGISHI, L. "Autobiographic praxis: studying the formation of teachers' knowledge". Journal of Curriculum Theorizing, 7 (4), 87-164, 1988.

BUTT, R.L. e RAYMOND, D. "Bringing reform to life: teachers' stories and professional development". Cambridge Journal of Education, 20 (3), 275-288, 1990.

CALDERHEAD, J. "Teachers' beliefs and knowledge". In: BERLINER, D. e CALFEE, R. (eds.), Handbook of educational psychology. Nova lorque: MacMillan, 1996, pp. 709-725.

CARTER, K. e ANDERS, D. "Program pedagogy". In: MURRAY, F.B. (ed.), The teacher educator's handbook: building a knowledge base for the preparation of teachers. San Fransisco: Jossey-Bass, 1996, pp. 557-592.

CARTER, K. e DOYLE, W. "Preconceptions in learning to teach". Educational forum, 59 (2) 186-95, 1995.

. "Personal narrative and life history in learning to teach". In: SIKULA, J.; BUTTERY, T.J. e GUYTON, E. (eds.), Handbook of research on teacher education, 2. ed. Nova lorque: MacMillan, 1996, pp. 120-142.

CLANDININ, D.J. Classroom practice: teacher images in action. Londres: Falmer, 1985.

CONNELLY, F.M. e CLANDININ, D.J. "Personal practical knowledge and the modes of knowing: relevance for teaching and learning". In: EISNER, E.W. (ed.), Learning and teaching the ways of knowing. (84 ${ }^{\text {th }}$ yearbook of the National Society for the Study of Education, Part 2). Chicago: University of Chicago Press, 1985.

DELBOS, G. e JORION, P. La transmission des savoirs. Paris: Éditions de la Maison des Sciences de l'Homme, 1990 (1. ed. em 1984).

DUBAR, C. La socialisation: construction des identités sociales et professionnelles. Paris: Armand Collin, 1991.

. "Formes identitaires et socialisation professionnelle". Revue Française de Sociologie, XXXIII (4), 505-529, 1992.

"À propos de l'insertion professionnelle: l'insertion comme articulation temporelle du biographique et du structurel". Revue Française de Sociologie, XXXV (2), 283-291, 1994. 
DUBET, F. Sociologie de l'expérience. Paris: Seuil, 1994.

GAUTHIER, C.; MARTINEAU, S.; DESBIENS, J.-F.; MALO, A. e SIMARD, D. Por uma teoria da pedagogia: pesquisas contemporâneas sobre o saber docente. Trad. do francês por Francisco Pereira de Lima. Ijuí: UNIJUÍ, 1998.

HOLT-REYNOLDS, D. "Personal history-based beliefs as relevant prior knowledge in coursework". American educational research journal, 29 (2), 325-349, 1992.

LACEY, C. The socialization of teachers. Londres: Methuen, 1977.

LESSARD, C. e TARDIF, M. La profession enseignante au Québec (19451990). Histoire, système et structures. Montreal: Presses de l'Université de Montréal, 1996.

MAESTRE, T.J. Biography, self and teacher education: A narrative study of the cycle of learning in a preser-vice curriculum course. Tese de doutorado. University of California, Berkeley, 1996.

MCDIARMID, G.-W.; BALL, D.L. e ANDERSON, C. "Why staying ahead one chapter just won't work: subject-specific pedagogy". In: REYNOLDS, M.C. (ed.), Knowledge base for the beginning teacher. Nova lorque: Pergamon Press, 1989, pp. 193-205.

MCDIARMID,G.-W. "Challenging prospective teachers' beliefs during early field experience: a quixotic under-taking?" Journal of Teacher Education, 41 (3), 12-20, 1990.

MONTMOLLIN, M. de. Savoir travailler. Le point de vue de l'ergonome. Dans savoirs théoriques et savoirs d'action (BARBIER, J.-M., dir.). Paris: PUF, 1996, pp. 189-199.

MOUSSALLY, E.J. A cultural portrait of preservice teachers: undergraduate teacher education at a northeastern United States private, urban university (private universities). Tese de doutorado. Boston University, 1992.

NAULT, T. Étude exploratoire de l'insertion professionnelle des enseignants débutants au niveau secondaire. Tese de doutorado. Université de Montréal, 1993.

PAQUAY, L.; ALTET, M.; CHARLIER, E. e PERRENOUD, P. Former des enseignants. Quelles stratégies? Quelles compétences? Bruxelas: De Boeck, 1996. 
RAYMOND, D. "Éclatement des savoirs et savoirs en rupture: une réplique à Van der Maren". Revue des Sciences de l'Éducation, 19 (4), 187-200, 1993a.

. "En formation à l'enseignement: des savoirs professionnels qui ont une longue histoire". Comunicação apresentada no simpósio "Savoirs professionnels et curriculum de formation de professionnels". Sexto Encontro Internacional do REF (Rede Internacional de Pesquisa em Educação e Formação). Toulouse, out., 1998.

. "Préconceptions des étudiants-maîtres et rapports aux savoirs pédagogiques et didactiques". Comunicação apresentada no colóquio organizado pelo CRIFPE sobre "Enseignement de la matière dans le contexte du travail pédagogique en classe: l'articulation didactiquepédagogique comme enjeu de formation". Congresso anual da ACFAS, Université Laval, 11 e 12 de maio de 1998, 1998a.

. "En formation à l'enseignement: des savoirs professionnels qui ont une longue histoire". Comunicação apresentada no simpósio "Savoirs professionnels et curriculum de formation de professionnels". Sexto Encontro Internacional da REF (Rede Internacional de Pesquisa em Educação e Formação). Toulouse, out., 1998b.

. e LENOIR, Y. (eds.). Enseignants de métier et formation initiale, des changements dans les rapports de formation à l'enseignement. Bruxelas: De Boeck, Perspectives en Éducation, AQUFOM, 1998.

.; BUTT, R.L. e YAMAGISHI, R. "Savoirs pré-professionnels et formation fondamentale: approche autobiographique". In: GAUTHIER, C.; MELLOUKI, M. e TARDIF, M. (dirs.), Le savoir des enseignants: unité et diversité. Montreal: Logiques, 1993, pp. 137-168.

RICHARDSON, V. "The role of attitudes and beliefs in learning to teach". In: SIKULA, J.; BUTTERY, T.J. e GUYTON, E. (eds.), Handbook of research on teacher education, 2. ed. Nova lorque: MacMillan, 1996, pp. 102-119.

SCHÖN, D.A. The reflective practitionner. Nova lorque: Basic Book, 1983.

TARDIF, M. e LESSARD, C. Le travail enseignant au quotidien. Contribution à l'étude du travail dans les métiers et les professions d'interactions humaines. Quebec: De Boeck/PUL, 1999. 
TARDIF, M.; LESSARD, C. e GAUTHIER, C. (dir.) Formation des maîtres et contextes sociaux. Perspectives internationales. Paris: Les Presses Universitaires de France, 1998.

TARDIF, M.; LESSARD, C. e LAHAYE, L. "Les enseignants des ordres d'enseignement primaire et secondaire face aux savoirs. Esquisse d'une problématique du savoir enseignant". Sociologie et Sociétés, vol. 23, 1 (55-70), 1991.

TERSSAC, G. de. Savoirs, compétences et travail. Dans savoirs théoriques et savoirs d'action (BARBIER, J.-M., dir.). Paris: PUF, 1996, pp. 223-247.

VEENMAN, S. "Perceived problems of beginning teachers". Review of Educational Research, 54 (2), 143-178, 1984.

WIDEEN, M.; MAYER-SMITH, J. e MOON, B. "A critical analysis of the research on learning to teach: making the case for an ecological perspective in inquiry". Review of Educational Research, 68 (2), 130-178, 1998. 